\title{
Detection of 16S rRNA Methylase Genes in Gram-Negative Bacilli Isolated from Hospitals in Changchun, China
}

\author{
Fan Zhao ${ }^{1}$, Hongyan $\mathrm{Shi}^{2}$, Jinghua $\mathrm{Li}^{2}$, Jiaqi Zhou' ${ }^{2}$ Yanbo Sun ${ }^{2 *}$ \\ ${ }^{1}$ Department of Orthopedics, China-Japan Union Hospital of Jilin University, Changchun, China; ${ }^{2}$ Department of Pathogen Biology, \\ Basic Medical College of Jilin University, Changchun, China. \\ Email: *sunyb@jlu.edu.cn
}

Received November $4^{\text {th }}, 2013$; revised December $3^{\text {rd }}, 2013$; accepted December $10^{\text {th }}, 2013$

Copyright (C) 2013 Fan Zhao et al. This is an open access article distributed under the Creative Commons Attribution License, which permits unrestricted use, distribution, and reproduction in any medium, provided the original work is properly cited.

\begin{abstract}
Methylation of $16 \mathrm{~S}$ rRNA is an important mechanism of aminoglycoside resistance among gram-negative pathogens. In this report, 16S rRNA methylase genes were amplified using PCR among gram-negative bacillus isolates from hospitals in the Changchun area of China and $16 \mathrm{~S}$ rRNA methylase genotypes $(\operatorname{arm\mathrm {A}}, r m t \mathrm{~B}, r m t \mathrm{~A}, r m t \mathrm{C}, r m t \mathrm{D}$, and $n p m \mathrm{~A})$ were identified by direct sequencing. Fifty of the isolates $(43.1 \%)$ harbored $16 \mathrm{~S}$ rRNA methylase genes. The common $16 \mathrm{~S}$ rRNA methylase genes were $\operatorname{rrm} \mathrm{A}$ and $r m t \mathrm{~B}(12.1 \%$ and $31.0 \%$, respectively), whereas the $r m t \mathrm{~A}, r m t \mathrm{C}, r m t \mathrm{D}$, and $n p m \mathrm{~A}$ genes were absent from the sample. It suggests that the predominant $16 \mathrm{~S}$ rRNA methylase genes among gramnegative bacilli in the Changchun area are $\operatorname{arm} \mathrm{A}$ and $r m t \mathrm{~B}$.
\end{abstract}

Keywords: 16S rRNA; Methylases; Gram-Negative Bacilli

\section{Introduction}

Aminoglycosides have strong antibacterial activity against gram-negative bacilli and gram-positive bacilli. Aminoglycosides are well received by clinicians because of their broad antimicrobial spectrum and efficacy. The irrational use of antibiotics is causing increasingly acute problems associated with antimicrobial resistance, however. The methylation of $16 \mathrm{~S}$ rRNAs in gram-negative bacilli is one of the mechanisms underlying strong resistance to aminoglycosides. Recent studies [1-2] showed that $16 \mathrm{~S}$ rRNA methylase could methylate the $30 \mathrm{~S}$ ribosomal subunit in gram-negative bacilli. 16S rRNA methylase can protect the target sites of the $30 \mathrm{~S}$ ribosomal subunit, preventing the aminoglycosides from combining with the $30 \mathrm{~S}$ ribosomal subunit.

Following the first discovery of $16 \mathrm{~S}$ rRNA methylase gene $\operatorname{arm} \mathrm{A}$ in France [3], other methylases such as $r m t \mathrm{~B}$, $r m t \mathrm{~A}$, and $r m t \mathrm{C}$ were found among gram-negative pathogens $[4,5]$. The predominant methylase genes in southern China are $\operatorname{arm} \mathrm{A}$ and $\operatorname{arm} \mathrm{B}$ [6]; however, the prevalence of $16 \mathrm{~S}$ rRNA methylases among clinical isolates of gramnegative bacilli in Changchun, Northeast of China, has not been previously assessed. $16 \mathrm{~S}$ rRNA methylase me-

\footnotetext{
"Corresponding author.
}

diates high-level resistance to aminoglycosides in gramnegative isolates, and some spices in gram-negative bacilli are major causes of nosocomial infections [7]. The aim of this study was to investigate the prevalence of $16 \mathrm{~S}$ rRNA methylases in aminoglycoside-resistant isolating from three hospitals in Changchun and to characterize the host bacteria.

\section{Materials and Methods}

\subsection{Isolates and Drugs}

One hundred and sixteen strains of gram-negative bacilli were isolated from China-Japan Union Hospital of Jilin University (Changchun, China), the Affiliated Hospital to Changchun University of Chinese Medicine (Changchun, China), and the Clinical Laboratory of Jilin Province People's Hospital (Changchun, China). The clinical isolates consisted of 33 Escherichia coli strains, 25 Klebsiella pneumoniae strains, 14 Enterobacter cloacae strains, 15 Acinetobacter baumannii strains, 19 Pseudomonas aeruginosa strains, and 10 Serratia marcescens strains. Identification of these isolates was done using the VITEK-32 system (Mérieux, France). Amikacin was provided by the National Institute for the Control of Pharmaceutical and Biological Products (batch number 130335-200204) (Bei- 
jing, China). Gentamicin was supplied by Beijing Dingguo Changsheng Biotech Co., Ltd. (batch number 1B310330) (Beijing, China).

\subsection{Testing for Antibiotic Susceptibility by Agar Dilution}

The susceptibilities of the 116 strains to amikacin and gentamicin were determined by agar dilution. Isolates that were able to grow at antibiotic concentrations above $16 \mathrm{mg} / \mathrm{L}$ were regarded as being resistant to the antibiotics; and those that were not able to grow at concentrations above $2 \mathrm{mg} / \mathrm{L}$ were regarded as sensitive.

\subsection{Extraction of Bacteria DNA}

One milliliter of bacterial culture was placed in a $1.5 \mathrm{~mL}$ centrifuge tube and centrifuged at 10,000 rpm for $1 \mathrm{~min}$. The supernatant was removed, and $100 \mu \mathrm{L}$ TE Buffer $(1$ $\mathrm{mol} / \mathrm{L}$ Tris-HCl, $\mathrm{pH} 8.0 ; 500 \mathrm{mmol} / \mathrm{L}$ EDTA, $\mathrm{pH} 8.0$ ) was added. Then, an equal volume of mixed phenol, chloroform, and isoamyl alcohol (25:24:1) was added. Vortex oscillation was then performed for $30 \mathrm{~s}$, and the mixture was subsequently centrifuged at $10,000 \mathrm{rpm}$ for $5 \mathrm{~min}$. The resulting supernatant was then stored at $-20^{\circ} \mathrm{C}$ until later use as the template for genetic testing.

\subsection{Primer Design and Detection of $16 \mathrm{~S}$ rRNA Methylase Genes}

Primers were self-designed for six different 16S rRNA methylase gene sequences available from GenBank. The primer sequences, target genes, and primer lengths are shown in Table 1. The conditions for producing PCR products with lengths greater than $500 \mathrm{bp}$ were: $2 \mathrm{~min}$ at $93^{\circ} \mathrm{C} ; 35$ cycles of $1 \mathrm{~min}$ at $93^{\circ} \mathrm{C}, 1 \mathrm{~min}$ at $55^{\circ} \mathrm{C}$, and 1 min at $72^{\circ} \mathrm{C}$; followed by $5 \mathrm{~min}$ at $72^{\circ} \mathrm{C}$. The conditions for producing PCR products with lengths less than 500 bp were: $5 \mathrm{~min}$ at $93^{\circ} \mathrm{C} ; 35$ cycles of $30 \mathrm{~s}$ at $93^{\circ} \mathrm{C}, 30 \mathrm{~s}$ at $55^{\circ} \mathrm{C}$, and $1 \mathrm{~min}$ at $72^{\circ} \mathrm{C}$; followed by $5 \min$ at $72^{\circ} \mathrm{C}$. After $2 \%$ agarose gel electrophoresis, the PCR products were observed under a gel imager and photos were taken.

\subsection{PCR Product Sequencing}

The PCR products were sent to Beijing Genomics Institute, (Beijing, China) for sequencing. The sequences were detected using the Chromas software and compared with those released by GenBank.

\section{Results}

\subsection{Results of Antibiotic Susceptibility Testing}

Among the 116 gram-negative bacilli, 16 E. coli strains, $1 \mathrm{~K}$. pneumoniae strain, 3 E. cloacae strains, $11 \mathrm{~A}$. baumannii strains, 10 P. aeruginosa strains, and 9 S. marces-
Table 1. Primer sequences for the six known 16S rRNA methylase genotypes.

\begin{tabular}{|c|c|c|}
\hline $\begin{array}{l}\text { Target } \\
\text { gene }\end{array}$ & Primer sequences $\left(5^{\prime} \rightarrow 3^{\prime}\right)$ & $\begin{array}{l}\text { Product } \\
\text { length (bp) }\end{array}$ \\
\hline $\operatorname{arm} \mathrm{A}$ & $\begin{array}{l}\text { P1: ATGGAT AAGAATGATGTTGTTAAG } \\
\text { P2: TTAT T TCTGAAATCCACTAGT AATTA }\end{array}$ & 774 \\
\hline$r m t \mathrm{~A}$ & $\begin{array}{l}\text { P1: ACTGTGATGGGATACGCGTC } \\
\text { P2:AGCGATATCCAACACACGATGG }\end{array}$ & 315 \\
\hline$r m t \mathrm{~B}$ & $\begin{array}{c}\text { P1: ATGAACATCAACGATGCCCTC } \\
\text { P2:TTATCCATTCTTTTTTATCAAGTATAT }\end{array}$ & 756 \\
\hline$r m t \mathrm{C}$ & $\begin{array}{l}\text { P1: ATGAAAACCAACGATAATTATC } \\
\text { P2:TTACAATCTCGATACGATAAAATAC }\end{array}$ & 846 \\
\hline$r m t \mathrm{D}$ & $\begin{array}{l}\text { P1:ATGAGCGAACTGAAGGAAAAACTGCT } \\
\text { P2:TCATTTTCGTTTCAGCACGTAAAACAG }\end{array}$ & 744 \\
\hline прт $\mathrm{A}$ & $\begin{array}{l}\text { P1:TTGGGTACTGGAGACGGTAG } \\
\text { P2: CAGCT TTGTATTGT TCGCTC }\end{array}$ & 421 \\
\hline
\end{tabular}

cens strains showed resistance to amikacin concentrations exceeding $16 \mathrm{mg} / \mathrm{L}$ (Table 2). Likewise, 26 E. coli strains, $11 \mathrm{~K}$. pneumoniae strains, 8 E. cloacae strains, 15 A. baumannii strains, 17 P. aeruginosa strains, and $10 \mathrm{~S}$. marcescens strains exhibited resistance to gentamycin concentrations exceeding $16 \mathrm{mg} / \mathrm{L}$ (Table 3).

\subsection{Results of 16S rRNA Methylase Genetic Testing}

Fifty (43.1\%) of the 116 isolates harbored $16 \mathrm{~S}$ rRNA methylase genes. The common $16 \mathrm{~S}$ rRNA methylase genes were $\operatorname{arm} \mathrm{A}(12.1 \%, 14 / 116)$ and $r m t \mathrm{~B}(31.0 \%, 36 / 116)$. All of the isolates were negative for the $r m t \mathrm{~A}, r m t \mathrm{C}$, $r m t \mathrm{D}$, and $n p m \mathrm{~A}$ genotypes (Table 4). Additionally, three of the $S$. marcescens strains harbored both $\operatorname{armA}$ and $r m t \mathrm{~B}$ and were highly resistant to both amikacin and gentamicin. An electrophoregram of the products of PCR amplification of $\operatorname{arm} \mathrm{A}$ and $r m t \mathrm{~B}$ is shown in Figures 1 and 2.

\subsection{Sequencing of $16 \mathrm{~S}$ rRNA Methylase}

The results of the direct sequencing of the armA and $r m t \mathrm{~B}$ genes isolated from our sample were compared with the corresponding sequences in the GenBank database, and the sequences in our sample were found to be identical to those in the database (arm A:HQ204573.1; rmt B:FJ539137.1).

\section{Discussion}

Aminoglycosides exert their antibacterial action by binding to the highly conserved A site of the 16S rRNA of the bacterial $30 \mathrm{~S}$ ribosomal subunits, interfering with protein synthesis with subsequent bacterial death. Furthermore, aminoglycosides have a broad antimicrobial 
Table 2. Susceptibilities of gram-negative bacilli to amikacin.

\begin{tabular}{ccc}
\hline Drug-resistant isolate & S strains (\%) & R strains (\%) \\
\hline Escherichia coli & $17(51.5)$ & $16(48.5)$ \\
Klebsiella pneumoniae & $24(96.0)$ & $1(4.0)$ \\
Enterobacter cloacae & $11(78.6)$ & $3(21.4)$ \\
Acinetobacter baumannii & $4(26.7)$ & $11(73.3)$ \\
Pseudomonas aeruginosa & $9(47.4)$ & $10(52.6)$ \\
Serratia marcescens & $1(10.0)$ & $9(90.0)$ \\
Total & $66(56.9)$ & $50(43.1)$ \\
\hline
\end{tabular}

S: Sensitive; R: Resistant.

Table 3. Susceptibilities of gram-negative bacilli to gentamicin.

\begin{tabular}{ccc}
\hline Drug-resistant isolate & S strains (\%) & R strains (\%) \\
\hline Escherichia coli & $7(21.2)$ & $26(78.8)$ \\
Klebsiella pneumoniae & $14(56.0)$ & $11(44.0)$ \\
Enterobacter cloacae & $6(42.9)$ & $8(57.1)$ \\
Acinetobacter baumannii & $0(0.0)$ & $15(100)$ \\
Pseudomonas aeruginosa & $2(10.5)$ & $17(89.5)$ \\
Serratia marcescens & $0(0.0)$ & $10(100)$ \\
Total & $29(25.0)$ & $87(75.0)$ \\
\hline
\end{tabular}

S: Sensitive; R: Resistant.

Table 4. Detection results of $16 \mathrm{~S}$ rRNA methylase genes.

\begin{tabular}{ccc}
\hline Drug-resistant isolates & $\operatorname{armA}(\%)$ & $r m t \mathrm{~B}(\%)$ \\
\hline Escherichia coli & $1(3.0)$ & $18(54.5)$ \\
Klebsiella pneumoniae & $0(0.0)$ & $0(0.0)$ \\
Enterobacter cloacae & $1(7.1)$ & $0(0.0)$ \\
Acinetobacter baumannii & $5(33.3)$ & $0(0.0)$ \\
Pseudomonas aeruginosa & $0(0.0)$ & $14(73.7)$ \\
Serratia marcescens & $7(70.0)$ & $4(40.0)$ \\
Total & $14(12.1)$ & $36(31.0)$ \\
\hline
\end{tabular}

Note: $r m t \mathrm{~A}, r m t \mathrm{C}, r m t \mathrm{D}$, and $n p m \mathrm{~A}$ are negative.

spectrum and produce synergistic effects with other kinds of antibiotics. Because of massive use of antibiotics including aminoglycosides, problems related to bacterial resistance to aminoglycosides are becoming very serious. Such resistance is achieved by enzymatic modification, changes in cellular membrane permeability, efflux pump activity, the phoP-phoQ system, or 16S rRNA methylase activity [10-12]. 16S rRNA methylase is usually encoded

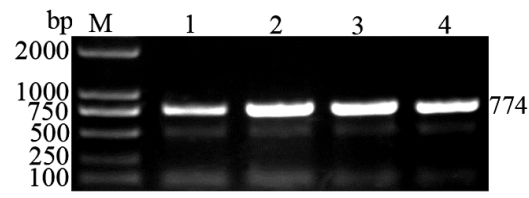

M: DNA Marker; Lanes 1-4: armA.

Figure 1. Electrophoregram of PCR amplified products of 16S rRNA methylase gene $\operatorname{armA}$.

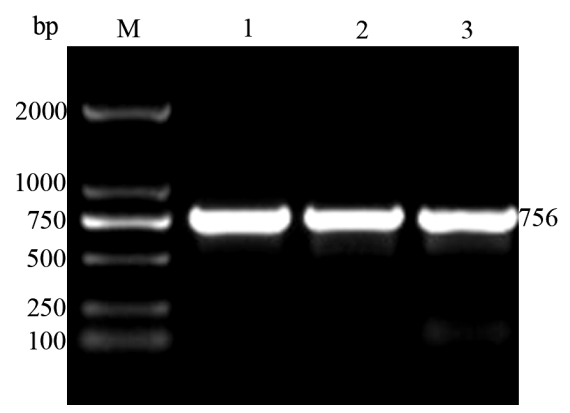

M: DNA Marker; Lanes 1-3: rmtB.

Figure 2. Electrophoregram of PCR amplified products of $16 \mathrm{~S}$ rRNA methylase gene $r m t B$.

by plasmids, and its transfer via plasmids has led to the rapid spread of $16 \mathrm{~S}$ rRNA methylase genes among bacilli $[13,15]$, causing great difficulties for clinical treatment.

Our study showed that $43.1 \%$ and $75 \%$ of a sample of 116 gram-negative bacillus isolates were resistant to amikacin and gentamicin, respectively. Except for the low resistance rates among the K. pneumoniae and E. cloacae strains, the resistance rates among the other strains of gram-negative bacilli were all greater than $45 \%$, indicating high rates of aminoglycoside resistance among gramnegative bacilli in the Changchun area. In terms of the 16S rRNA methylase genetic testing, the frequency of $r m t \mathrm{~B}(31.0 \%)$ in our sample was higher than that of arm $\mathrm{A}$ $(12.1 \%)$. Furthermore, $r m t \mathrm{~B}$ is mainly distributed among E. coli $(54.5 \%)$ and $P$. aeruginosa $(73.7 \%)$ strains; whereas $\operatorname{arm} \mathrm{A}$ is mainly distributed among A. baumannii (33.3\%) and $S$. marcescens $(70 \%)$ strains. We did not detect any 16S rRNA methylase genes among $25 \mathrm{~K}$. pneumoniae strains; and we only found $1 \mathrm{rmt}$ A gene among 14 strains of E. cloacae (7.1\%). The three $S$. marcescens strains that carried both arm $\mathrm{A}$ and $r m t \mathrm{~B}$ showed strong resistance to both amikacin and gentamicin. In our study, the frequency of aminoglycoside resistance among the 116 strains of gram-negative bacilli was higher than the frequency of 16S rRNA methylase genes, suggesting that the drug-resistant phenotypes were not totally consistent. Therefore, some of the aminoglycoside resistance in our sample was likely caused by other antibiotic resistance mechanisms such as the production of AME genes, changes in cellular membrane permeability, efflux pump activity, or the phoP-phoQ system.

In terms of the distribution of $16 \mathrm{~S}$ rRNA methylase ge- 
nes, only the arm $\mathrm{A}$ and $r m t \mathrm{~B}$ genes were detected in our study, suggesting that $\operatorname{arm} \mathrm{A}$ and $r m t \mathrm{~B}$ are the two main $16 \mathrm{~S}$ rRNA methylase genes in the Changchun area, which is consistent with relevant domestic studies [16, 17]. The $\operatorname{arm} \mathrm{A}$ and $r m t \mathrm{~B}$ genes are also the most common genotypes in other Asian countries such as South Korea [18] and Japan [19]. The most commonly detected 16S rRNA methylase genes in European countries such

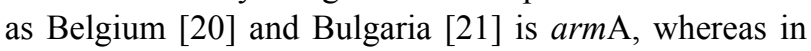
Brazil it is $r m t \mathrm{~B}$ [22]. According to our data, high-level aminoglycoside resistance in clinical isolates conferred by $16 \mathrm{~S}$ rRNA methylase is of great concern in Changchun area. Hence, clinicians must pay more attention to the rational use of such drugs to reduce the frequencies of drug-resistant bacteria under the selective pressure by antibiotics.

\section{Conclusion}

In conclusion, our experimental results suggest that the predominant $16 \mathrm{~S}$ rRNA methylase genes among gramnegative bacillus isolates from Changchun area, Northeast of China, are $\operatorname{arm} \mathrm{A}$ and $r m t \mathrm{~B}$. Aminoglycoside-resistant isolates producing arm $\mathrm{A}$ or $r m t \mathrm{~B}$ may become a major therapeutic threat in the future.

\section{Acknowledgements}

The study was supported by both National Natural Science Foundation of China (Grant number: 81150037) and High-tech industry development projects of Jilin Province (Grant number: 2009633).

\section{REFERENCES}

[1] K. Yokoyama, Y. Doi, K. Yamane, H. Kurokawa, N. Shibata, K. Shibayama, T. Yagi, H. Kato and Y. Arakawa, "Acquisition of 16S rRNA Methylase Gene in Pseudomonas Aeruginosa," Lancet, Vol. 362, No. 9399, 2003, pp. 1888-1893.

http://dx.doi.org/10.1016/S0140-6736(03)14959-8

[2] B. Bercot, L. Poirel and P. Nordmann, "Plasmid-Mediated 16S rRNA Methylases among Extended-Spectrum $\beta$ Lactamase-Producing Enterobateriaceae Isolates," Antimicrobial Agents and Chemotherapy, Vol. 52 No. 12, 2008, pp. 4526-4527. http://dx.doi.org/10.1128/AAC.00882-08

[3] M. Galimand, P. Courvalin and T. Lambert, "PlasmidMediated High Level Resistance to Aminoglycoside in Enterobacteriaceae Due to 16S rRNA Methylation," Antimicrobial Agents and Chemotherapy, Vol. 47, No. 8, 2003, pp. 2565-2571.

http://dx.doi.org/10.1128/AAC.47.8.2565-2571.2003

[4] J. Wachino, K. Yamane, K, Shibayama, H. Kurokawa, N. Shibata, S. Suzuki, Y. Doi, K. Kimura, Y. Ike and Y. Arakawa, "Novel Plasmid-Mediated 16S rRNA Methylase, rmtC, Found in a Proteous Mirabilis Isolate Demon- strating Extraordinary High-Level Resistance against Various Aminoglycosides," Antimicrobial Agents and Chemotherapy, Vol. 50, No. 1, 2006, pp. 178-184. http://dx.doi.org/10.1128/AAC.50.1.178-184.2006

[5] K. Yamane, J. Wachino, Y. Doi, H. Kurokawa and Y. Arakawa, "Global Spread of Multiple Aminoglycoside Genes," Emerging Infectious Disease, Vol. 11, No. 6, 2005, pp. 951-953. http://dx.doi.org/10.3201/eid1106.040924

[6] F. Yu, L. Wang, J. Pan, D. Yao, C. Chen, T. Zhu, Q. Lou, J. Hu, Y. Wu, X. Zhang, Z. Chen and D. Qu, "Prevalence of 16S rRNA Methylase Genes in Klebsiella Pneumoniae Isolates from a Chinese Teaching Hospital: Coexistence of rmtB and armA Genes in the Same Isolate," Diagnostic Microbiology and Infectious Disease, Vol. 64, No. 1, 2009, pp. 57-63.

http://dx.doi.org/10.1016/j.diagmicrobio.2009.01.020

[7] B. Li, X. Zhang, J. Li and Y. Sun, "Genotypes and Distribution of Extended-Spectrum $\beta$-Lactamases in Gram-Negative Bacilli Isolated from Changchun Area," Journal of Jilin University (Medicine Edition), Vol. 36, No. 1, 2010, pp. 205-209.

[8] J. Zhu, D. Xiao, R. Jiang and K. Wu, "Investigation of Aminoglycoside Modifying Enzyme Genes and 16S rRNA Methylase Genes in Multidrug Resistant Klebsiella Pneumoniae," Chinese Journal of Nosocomiology, Vol. 22, No. 17, 2012, pp. 3690-3693.

[9] Y. Deng, Z. Zeng, S. Chen, L. He, Y. Liu, C. Wu, Z. Chen, Q. Yao, J. Hou, T. Yang and J. Liu, "Dissemination of IncFII Plasmids Carring rmtB and qepA in Escherichia coli from Pigs, Farm Workers and the Environment," Clinical Microbiology and Infection, Vol. 17, No. 11, 2011, pp. 1740-1745. http://dx.doi.org/10.1111/j.1469-0691.2011.03472.x

[10] L. Kotra, J. Haddad and S. Mobashery, "Aminoglyeosides: Perspectives on Mechanisms of Action and Resistance and Strategies to Counter Resistance," Antimicrobial Agents and Chemotherapy, Vol. 44, No. 12, 2000, pp. 3249-3256. http://dx.doi.org/10.1128/AAC.44.12.3249-3256.2000

[11] S. Islam, H. Oh, S. Jalal, F. Karpati, O. Ciofu, N. Høiby and B Wretlind, "Chromosomal Mechanisms of Aminoglycoside Resistance in Pseudomonas Aeruginosa Isolates from Cystic Fibrosis Patients," Clinical Microbiology and Infection, Vol. 15, No. 1, 2009, pp. 60-66.

http://dx.doi.org/10.1111/j.1469-0691.2008.02097.x

[12] E. Macfarlan, E. Kwasnicka and R. Hancock, "Role of Pseudomonas Aeruginosa PhoP-PhoQ in Resistance to Antimicrobial Cationic Peptides and Aminoglycosides," Microbiology, Vol. 146, No. 10, 2000, pp. 2543-2554.

[13] Y. Doi, A. C. Ghilardi, J. Adams, D. de Olivera Garcia and D. L. Paterson, "High Prevalence of Metallo- $\beta$-Lactamase and 16SrRNA Methylase Coproduction among Imipenem-Resistant Pseudomonas Aeruginosa Isolates in Brazil," Antimicrobial and Agents Chemotherapy, Vol. 51, No. 9, 2007, pp. 3388-3390. http://dx.doi.org/10.1128/AAC.00443-07

[14] J. Wachino and Y. Arakawa., "Exogenously Acquired 16S rRNA Methyltransferases Found in Aminoglycoside-Resistant Pathogenic Gram-Negative Bacteria: An Update," Drug Resistance Updates, Vol. 15, No. 3, 2012, pp. 133- 
148. http://dx.doi.org/10.1016/j.drup.2012.05.001

[15] Y. J. Park, "Aminoglycoside Resistance in Gram-Negative Bacilli," Korean Journal of Clinical Microbiology, Vol. 12, No. 2, 2009, pp. 57-61. http://dx.doi.org/10.5145/KJCM.2009.12.2.57

[16] J. Cui, S. Zhao, Y. Qin, T. Gao, X. Wang and G. Feng, "Investigation of Related Genes of Aminoglycoside Resistant on Multi-drug Resistance Pseudomonas Aeruginosa," Chinese Journal of Nosocomiology, Vol. 20, No. 20, 2010, pp. 3099-3012.

[17] Y. Li, Y. Wu, H. Li and Y. Yang, "Investigation of 16S rRNA Methylase Genes in Gentamicin-Resistant Enterobacter Cloacae," Chinese Journal of Microecology, Vol. 23, No. 7, 2011, pp. 612-614.

[18] M. Gurung, D. C. Moon, M. D. Tamang, J. Kim, Y. C. Lee, S. Y. Seol, D. T. Cho and J. C. Lee, "Emergence of 16S rRNA Methylase Gene armA and Cocarriage of blaIMP-1 in Pseudomonas Aeruginosa Isolates from South Korea," Diagnostic Microbiology and Infectious Disease, Vol. 68, No. 4, 2010, pp. 468-470. http://dx.doi.org/10.1016/i.diagmicrobio.2010.07.021

[19] Y. Doi, K. Yokoyama, K. Yamane, J. Wachino, N. Shibata, T. Yagi, K. Shibayama, H. Kato and Y Arakawa, "Plasmid-Mediated 16S rRNA Methylase in Serratia Mar- cescens Conferring High-Level Resistance to Aminoglycosides," Antimicrobial Agents and Chemotherapy, Vol. 48, No. 2, 2004, pp. 491-496. http://dx.doi.org/10.1128/AAC.48.2.491-496.2004

[20] P. Bogaerts, M. Galimand, C. Bauraing, A. Deplano, R. Vanhoof, R. De Mendonca, H. Rodriquenz-Villalobos, M. Struelens and Y Glupczynski, "Emergence of ArmA and RmtB Aminoglycoside Resistance 16S rRNA Methylases in Belgium," Journal of Antimicrobial Chemotherapy, Vol. 59, No. 3, 2007, pp. 459-464. http://dx.doi.org/10.1093/jac/dkl527

[21] S. Sabtcheva, T. Saga, T. Kantardjiev, M. Ivanova, Y. Ishii and M. Kaku, "Nosocomial Spread of Arma-Mediated High-Level Aminoglycoside Resistance in Enterobacteriaceae Isolates Producing CTX-M-3 Beta-Lactamase in a Cancer Hospital in Bulgaria," Journal of Chemotherapy, Vol. 20, No. 5, 2008, pp. 593-599.

[22] Y. Doi, G. Oliveira, J. Adams and D. L. Paterson, "Coproduction of Novel 16S rRNA Methylase RmtD and Metallo- $\beta$-Lactamase SPM-1 in a Panresistant Pseudomonas Aeruginosa Isolate from Brazil," Antimicrobial Agents and Chemothearapy, Vol. 51, No. 3, 2007, pp. 852-856. http://dx.doi.org/10.1128/AAC.01345-06 